\title{
Diversity of rotifer communities in lakes of the Suwalki Landscape Park
}

\author{
Jolanta Ejsmont-Karabin $^{1^{*}}$, Andrzej Górniak ${ }^{2}$, Maciej Karpowicz ${ }^{2}$ \\ ${ }^{1}$ Nencki Institute of Experimental Biology, Polish Academy of Sciences, Pasteura 3, 02-093 Warszawa, Poland; \\ e-mail: j.karabin@nencki.gov.pl (*corresponding author) \\ ${ }^{2}$ University of Bialystok, Institute of Biology, Ciołkowskiego 1J, 15-245 Bialystok, Poland
}

\begin{abstract}
Studies of summer rotifer fauna of 11 shallow and 6 deep lakes of the Suwałki Landscape Park were conducted in an aim to assess the role of lake depth and biotic and abiotic factors in determining the diversity of rotifer communities in lakes undergoing a natural rate of eutrophication not accelerated by anthropopression. Some differences were observed when the group of shallow lakes was compared with that of deep lakes. The former were more differentiated as regards a list of rotifer species, partly due to the high proportion of species with low frequency. Consequently, their faunal originality was markedly higher and values of the percentage similarity of rotifer communities were much lower than in deep lakes. Species richness of rotifer fauna was also dependent on the trophic state of the studied lakes, the character of a nutrient limiting primary production, as well as biomass of diatoms and green algae.
\end{abstract}

Key words: Rotifera, species richness, shallow lakes, stratified lakes

\section{Introduction}

Pelagic waters in lakes are usually poorer in species than littoral habitats (Segers and De Smet 2008). The reason for this is a lack of differentiated habitats in open waters. The factor which should differentiate the zooplankton niches is, therefore diversity of food, which in turn, depends on the availability of nutrients and light. The shape of the relationship between rotifer diversity and productivity of freshwaters is still under study, but it is often suggested that moderately productive waters involve communities of plankton richer in species. In the studies of Dodson et al. (2000), rotifer species richness varied in a unimodal fashion with increased productivity. Another factor that affects pelagic waters and their fauna is the depth of a lake (Keller and Conlon 1994). Studies of Allan et al. (1999) have shown that aspects of lake morphology, like area and depth were markedly more important than other environmental features as correlates of assemblage richness.

The aim of the studies was to assess the role of lake depth as well as biotic and abiotic factors in determining the diversity of rotifer communities in lakes undergoing a natural rate of eutrophication not accelerated by agriculture, settlement and tourism.

\section{Methods}

Samples were taken at the end of July 2015 at the deepest place of six dimictic and 11 polymictic lakes (Table 1). Rotifers were sampled with a 2-litre sampler

Table 1. Morphometric characteristics of the Suwałki Landscape Park lakes (data according to Borowiak et al. 2016)

\begin{tabular}{lccc}
\hline \multicolumn{1}{c}{ Lake } & Area [ha] & Maximum depth [m] & Mean depth [m] \\
\hline Hańcza & \multicolumn{3}{c}{ Dimictic lakes } \\
\hline Jaczno & 403.6 & 105.6 & 39.1 \\
\hline Kamenduł & 25.3 & 25.7 & 9.8 \\
\hline Kojle & 17.3 & 26.2 & 7.0 \\
\hline Perty & 19.5 & 32.3 & 9.7 \\
\hline Szurpiły & 84.4 & 32.6 & 7.4 \\
\hline & & 47.1 & 11.2 \\
\hline Boczniel & 19.2 & 3.9 & 1.3 \\
\hline Krajwelek & 5.5 & 8.8 & 2.8 \\
\hline Linówek & 2.9 & 5.9 & 2.4 \\
\hline Łuśnin & 0.47 & 3.0 & 1.5 \\
\hline Okrągłe & 15.0 & 7.4 & 4.3 \\
\hline Postawelek & 3.4 & 4.0 & 2.0 \\
\hline Purwin & 1.41 & 4.3 & 2.8 \\
\hline Purwinek & 0.44 & 3.3 & 1.5 \\
\hline Snouda & 0.49 & 4.5 & 2.0 \\
\hline Udziejek & 7.01 & 6.9 & 3.3 \\
\hline Wodziłki & 3.73 & 5.4 & 3.1 \\
\hline
\end{tabular}


Table 2. Faunistic characteristics of rotifer communities in polymictic and dimictic lakes of the Suwałki Landscape Park (data for 2015)

\begin{tabular}{lcccl}
\hline \multicolumn{1}{c}{ Lake } & Number of species & Index of faunal originality & Shnnon's species diversity & \multicolumn{1}{c}{ Dominant rotiferspecies } \\
\hline Hańcza & 22 & \multicolumn{3}{c}{ Dimictic lakes } \\
\hline Jaczno & 23 & 0.38 & 2.77 & Keratella cochlearis \\
\hline Kamenduł & 16 & 0.34 & 1.35 & Keratella cochlearis \\
\hline Kojle & 16 & 0.22 & 2.06 & Polyarthra vulgaris; K. cochlearis \\
\hline Perty & 20 & 0.28 & 2.10 & Keratella cochlearis \\
\hline Szurpiły & 24 & 0.32 & 1.75 & Polyarthra vulgaris; K. cochlearis \\
\hline & & 0.30 & 2.91 & Keratella cochlearis \\
\hline Boczniel & 14 & & Shallow lakes & \\
\hline Krajwelek & 12 & 0.50 & 2.62 & Polyarthra remata \\
\hline Linówek & 4 & 0.30 & 2.17 & Keratella cochlearis \\
\hline Łuśnin & 7 & 0.36 & 1.28 & Polyarthra remata \\
\hline Okrągłe & 16 & 0.44 & 1.14 & Keratella cochlearis \\
\hline Postawelek & 5 & 0.42 & 2.56 & Pompholyx sulcata, K. cochlearis \\
\hline Purwin & 7 & 0.47 & 2.00 & Lack of dominants \\
\hline Purwinek & 3 & 0.43 & 1.37 & Keratella cochlearis \\
\hline Snouda & 12 & 0.47 & 1.45 & Keratella cochlearis \\
\hline Udziejek & 17 & 0.55 & 2.64 & Anuraeopsis fissa \\
\hline Wodziłki & 5 & 0.42 & 2.76 & Keratella cochlearis \\
\hline
\end{tabular}

at every $1 \mathrm{~m}$ depth and pooled for layers of epi-, metaand hypolimnion in stratified lakes and from the surface to the bottom in shallow lakes. The samples were concentrated with a plankton net of $30 \mu \mathrm{m}$ mesh size and fixed in $4 \%$ formalin. Rotifers were counted and examined under a miscroscope NIKON Eclipse Ni-U in a subsample equal to 1 litre of lake water.

An index of faunal originality (IFO) (based on floral originality in Puchalski 1987) was used to assess differences between lakes as regards the species structure of their of rotifer fauna:

$$
\mathrm{IFO}=\left(\sum 1 / \mathrm{M}\right) / \mathrm{S}
$$

where: $M=$ number of samples in which a species occurs; $S=$ number of species in a sample. The maximum value of the index is 1.0, if species found in a lake were not found in any of other lakes.

Rotifer communities were compared using the index of percentage similarity of community (PSC) (Whittaker and Fairbanks 1958): PSC $=100-0.5 \sum(a-b)$ $=\sum \min .(a, b)$, where $\mathrm{a}$ and $\mathrm{b}$ are percentages of individuals of each species in total numbers of the communities of lakes A and B, compared in pairs. The index takes into account the quantitative relations between different pairs of species.

Statistical analyses were conducted with the application of STATISTICA version 9.0 (StatSoft, Inc.). They included correlations between chemical and biological parameters and species richness of rotifer communities. Probability levels of $\leq 0.05$ were considered significant.

\section{Results}

In 2015 in shallow lakes of the Park 46 rotifer species were found. However, as many as $50 \%$ of them were detected in a single lake, and not one had 100\% frequency. The most frequent species was detritophagous Keratella cochlearis (Gosse) (Table 2). Relatively frequent were also algivorous Gastopus stylifer Imhof, Polyarthra remata Skorikov and $P$. vulgaris Carlin. A very high proportion of species with low frequency contributed to the high value of the index of species originality (Table 2), which ranged from 0.30 to 0.70 . This means that shallow lakes of the Suwałki Landscape Park are strongly differentiated as regards the list of rotifer species encountered during the summer stagnation period. This statement is confirmed by the relatively low mean values of percentage similarity of communities (when compared in pairs - a lake with all the remaining polymictic lakes) (Fig. 1). Rotifer communities of Lake Wodziłki and Lake Postawelek were the least similar to the communities of all the studied shallow lakes. These two lakes were characterized by very low densities of their rotifer fauna (Ejsmont-Karabin et al. 2016) devoid of dominants. High differentiation of species structure in polymictic lakes is also well illustrated by very high values of standard deviation for all lakes, with the exception of Wodziłki and Postawelek, whose rotifer faunas were equally different from each compared community (Fig. 1).

In the stratified lakes rotifer communities were very similar and dominated by species that were also the most frequent in shallow lakes, i.e. Keratella coch- 


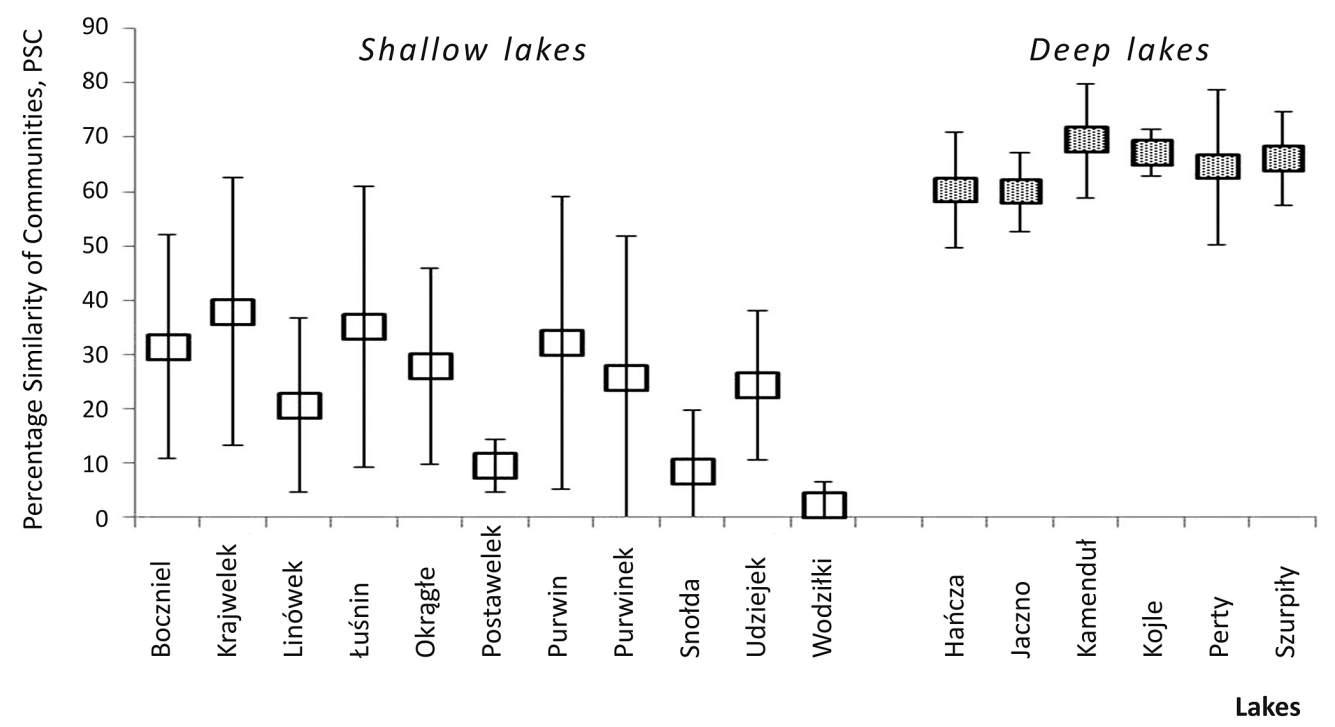

Fig. 1. Mean values $( \pm S D)$ of the Index of Percentage Similarity of Communities of Rotifera (PSC) in shallow and deep lakes of the Suwałki Landscape Park; mean values were calculated for the rotifer community of a given lake versus communities in all the remaining lakes of the same type of mixis

learis and/or Polyarthra vulgaris, accompanied by relatively abundant Gastropus styliferand Polyarthra rema$t a$. Their contribution to rotifer numbers was relatively similar, therefore the percentage similarity (PSC) index had values markedly higher than in shallow lakes. They ranged from 59.9 for rotifers of Lake Jaczno to 69.4 for Lake Kamenduł (Fig. 1). Consequently, the index of faunal originality was much lower than that noted in shallow lakes, and it ranged from 0.22 in Lake Kamenduł to 0.38 in Lake Hańcza (Table 2).

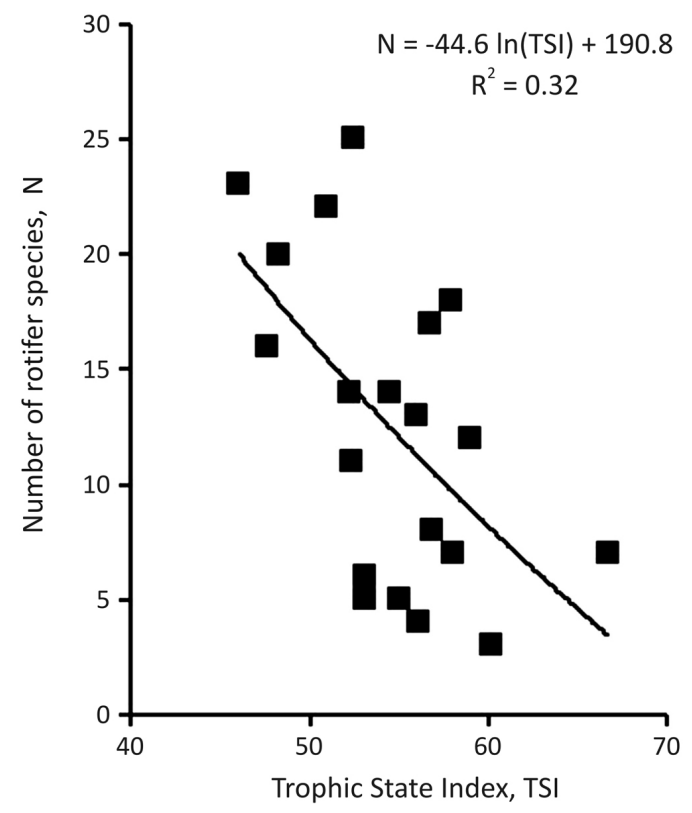

Fig. 2. Relationship between trophic state index calculated from Ptotal and chlorophyll- $a$ concentrations and number of rotifer species in epilimnion of all studied lakes of the Suwałki Landscape Park
Correlations made for the number of rotifer species versus trophic state indices and chemical (acc. to Górniak et al. 2016) and biological data for the set of lakes studied in 2015 (Figs 2-5) revealed only four significant relationships. There was a significant $(\mathrm{p}=$ 0.009) relationship between trophic state index (TSI) calculated from mean values of total phosphorus and chlorophyll- $a$ (acc. to Carlson 1977) and the number of rotifer species (Fig. 2). The number of rotifer species was also significantly correlated with the ratio of miner-

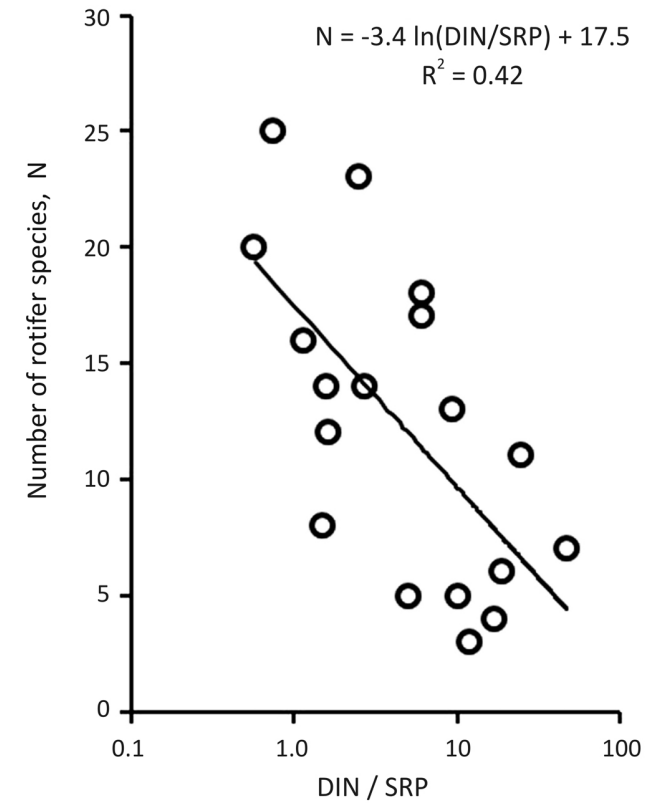

Fig. 3. Relationship between the ratio of mineral forms of nitrogen (DIN) and phosphorus (SRP) and number of rotifer species in epilimnion of all studied lakes of the Suwałki Landscape Park 


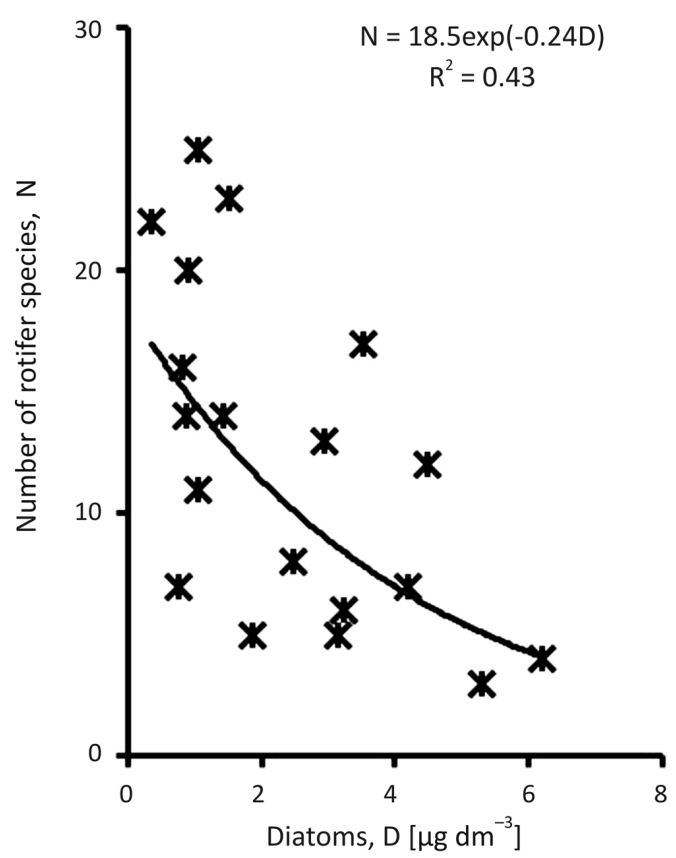

Fig. 4. Relationship between biomass of diatoms (in chlorophyll$a$ units) concentrations and number of rotifer species in epilimnion of all studied lakes of the Suwałki Landscape Park

al forms of nitrogen and phosphorus (Fig. 3; p = 0.004), which may indicate that a character of a factor limiting primary production plays a role (probably indirectly) in creating niches for rotifer fauna. With increasing limitation by phosphorus the number of rotifer species decreases. Species richness of rotifer fauna was also correlated with biomass of two groups of phytoplankton expressed in chlorophyll- $a$ units (acc. to Karpowicz et al. 2016): diatoms (Fig. 4; $\mathrm{p}=0.003$ ) and green algae (Fig. 5; $\mathrm{p}=0.009$ ).

\section{Discussion}

The most common theory describing the functioning of shallow lakes is that lakes tend to shift between a clear and a turbid state (Meijer et al. 1989). However, even though this spectacular shift between alternative states has been confirmed by many observations, it is probably typical for rapidly changing trophic conditions. In shallow lakes undergoing slow, natural eutrophication we should expect rather a kind of continuum with gradual species replacement. According to Sheffer and van Nes (2007) spatial heterogeneity, changes of processes of internal cyclic or chaotic dynamics, effects of changes in climatic conditions and hydrology complicate the process of changes in the structure of the biota of shallow lakes. This may also explain the high values of species originality and low values of the index of percentage similarity of rotifer communities in this group of lakes.

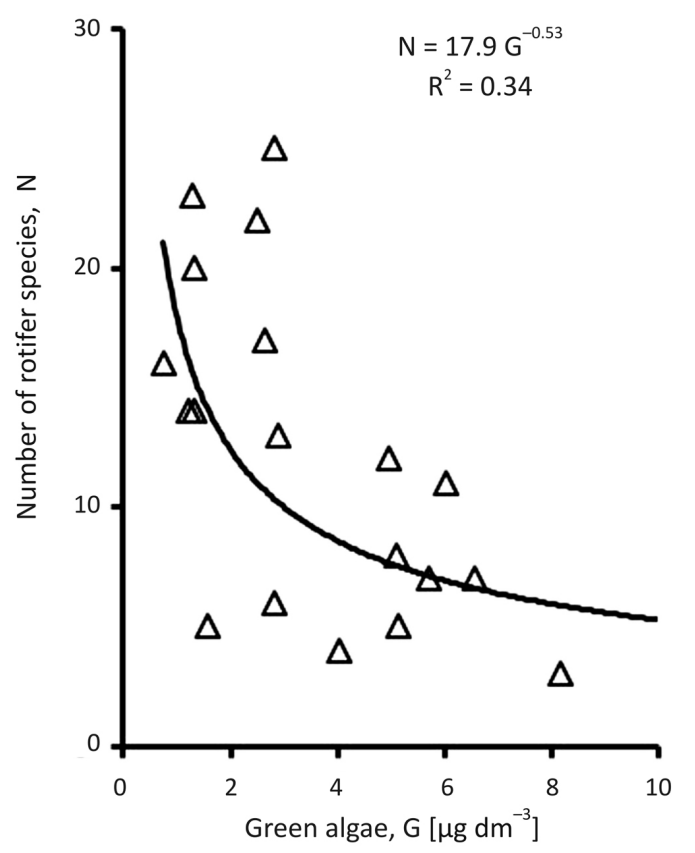

Fig. 5. Relationship between biomass of green algae (in chlorophyll$a$ units) concentrations and number of rotifer species in epilimnion of all studied lakes of the Suwałki Landscape Park

Disturbance may be another abiotic parameter dependent on the depth of the studied aquatic ecosystems (Connell 1978; Flöder and Sommer 1999). Lakes of smaller area and lower depth are probably more disturbed than deep and large lakes and this promotes, according to the Intermediate Disturbance Hypothesis (Connell 1978), higher diversity of plankton communities. Similarly, in the studies of Hessen et al. (2006) zooplankton species richness was inversely correlated both with lake surface area and with lake maximum depth.

The relationship between species number and lake productivity (and thus, their trophic state) is often reported as unimodal (Leibold 1999; Dodson et al. 2000). The different character of the relationship in our studies may be explained by a lack of the lowest values of trophy (oligotrophy) from which we could expect a low richness of rotifer fauna.

In general, studies of lakes of the Suwałki Landscape Park confirmed the conclusion of Hessen et al. (2006) that lake production measured as algal biomass is the major control of zooplankton richness as the number of rotifer species was significantly correlated with biomass of two important groups of phytoplankton, diatomes and green algae.

\section{References}

Allen A.P., Whittier T.R., Kaufmann P.R., Larsen D.P., O'Connor R.J., 1999, Concordance of taxonomic richness patterns across multiple assemblages in lakes of the 
northeastern United States, Can. J. Fish. Aquat. Sci. 56(5): 739-747.

Borowiak D., Nowiński K., Grabowska K., 2016, A new bathymetric survey of the Suwałki Landscape Park lakes, Limnol. Rev. 16(4): 185-197.

Carlson R.E., 1977, Trophic state index for lakes, Limnol. Oceanogr. 22(2): 361-369.

Connell J., 1978, Diversity in tropical rain forests and coral reefs, Science 199(4335):1304-1310.

Dodson S.I., Arnott S.E., Cottingham K.L., 2000, The relationship in lake communities between primary productivity and species richness, Ecology 81(10): 2662-2679.

Flöder S., Sommer U., 1999, Diversity in planktonic communities: an experimental test of the intermediate disturbance hypothesis, Limnol. Oceanogr. 44(4): 1114-1119.

Górniak A., Więcko A., Karpowicz M., 2016, Changes in the trophic status of lakes in the Suwałki Landscape Park (NE Poland), Limnol. Rev. 16(4): 221-227.

Hessen D.O., Faafeng B.A., Smith V.H., Bakkestuen V., Walseng B., 2006, Extrinsic and intrinsic controls of zooplankton diversity in lakes, Ecology 87(2): 433-443.

Karpowicz M., Górniak A., Więcko A., Cudowski A., 2016, The variability of summer phytoplankton communities in different types of lakes in Suwałki Landscape Park, Limnol. Rev. 16(4): 229-236.

Keller W., Conlon M., 1994, Crustacean Zooplankton Communities and Lake Morphometry in Precambrian Shield Lakes, Can. J. Fish. Aquat. Sci. 51(11): 2424-2434.

Leibold M.A., 1999, Biodiversity and nutrient enrichment in pond plankton communities, Evol. Ecol. Res. 1: 73-95.

Meijer M. L., Raat A. J., Doef R. W., 1989, Restoration by biomanipulation of Lake Bleiswijkse Zoom the Netherlands first results, Hydrobiol. Bull. 23: 49-58.

Puchalski W., 1987, Ugrupowania fitoplanktonu poeksploatacyjnych zbiorników wodnych (Phytoplankton assemblages in after-exploitation reservoirs) [Ph.D. Thesis], Institute of Ecology PAS, Dziekanów Leśny, 205 pp.

Segers H., De Smet W.H., 2008, Diversity and endemism in Rotifera: a review, and Keratella Bory de St Vincent, Biodivers. Conserv. 17(2): 303-316.

Scheffer M., van Nes E.H., 2007, Shallow lakes theory revisited: various alternative regimesdriven by climate, nutrients, depth and lake size, Hydrobiologia 584: 455-466.

Whittaker R.H., Fairbanks C.W, 1968, A study of plankton copepod communities in the Columbia Basin, Southeastern Washington, Ecology 39: 46-65. 